\title{
Efficacy and Safety of Prophylactic Intracameral Gatifloxacin Injection in Cataract Surgery: 1 Year Results
}

\author{
Ayşegül Penbe, ${ }^{1}$ Işıl Kutlutürk Karagöz, ${ }^{2}$ Mehmet Atakan, ${ }^{3}$ Yusuf Özertürk ${ }^{4}$
}

'Department of Eye Diseases, Kartal Yavuz Selim State Hospital İstanbul, Turkey

${ }^{2}$ Department of Eye Diseases, Ümraniye Training and Research Hospital, İstanbul, Turkey ${ }^{3}$ Department of Eye Diseases, Aksaray State Hospital, İstanbul, Turkey

${ }^{4}$ Department of Eye Diseases, Kartal Dr. Lütfi Kırdar Training and Research Hospital, İstanbul, Turkey

Submitted: 27.10.2016 Accepted: 17.11.2017

Correspondence: Ayşegül Penbe, Kartal Yavuz Selim Devlet Hastanesi, Göz Hastalıkları Kliniğ Kartal, İstanbul, Turkey

E-mail: dr.aysegulp@gmail.com

口ista

Keywords: Cataract; cefuroxime; endophthalmitis; gatifloxacin; intracameral; prophylaxis.

\begin{abstract}
Objective: The aim of this study was to compare the effectiveness and safety of an intracameral injection of gatifloxacin with cefuroxime as prophylaxis for endophthalmitis in cataract surgery.
\end{abstract}

Methods: In this retrospective comparative case series, 4 I eyes of 33 patients were separated into 2 groups. In the first group, an intracameral injection of cefuroxime $(1 \mathrm{mg} / 0.1 \mathrm{~mL})$ was administered to 18 eyes, and an intracameral injection of gatifloxacin $(0.3 \mathrm{mg} / 0.1 \mathrm{~mL})$ was administered to 23 eyes in the second group. The best corrected visual acuity (BCVA), endothelial cell density (CD), endothelial cell coefficient of variation (CV), and central macular thickness (CMT) were evaluated at baseline and I, 3, 6, and I 2 months after surgery.

Results: No instance of acute/chronic endophthalmitis, cystoid macular edema, or bullous keratopathy was seen in any patient at the end of I year of follow-up. At postoperative month I, a statistically significant increase in BCVA was seen in both groups, as well as a decrease in CD, and a statistically insignificant increase in CMT. However, the 2 groups were found statistically similar in terms of BCVA, CD, CV, and CMT values obtained in subsequent follow-ups ( $p>0.05)$.

Conclusion: VA, CMT, and endothelial cell changes were similar in both the cefuroxime group and the gatifloxacin group. Intracameral administration of $0.3 \mathrm{mg} / 0.1 \mathrm{~mL}$ gatifloxacin or I mg/0.I mL cefuroxime is effective and safe as endophthalmitis prophylaxis, given the statistically and clinically insignificant increase in CMT seen in both groups at the postoperative first month.

\section{INTRODUCTION}

Endophthalmitis is a rarely seen intraocular inflammation that may occur as a complication of eye surgery, nonsurgical trauma, or systemic infection, and may result in serious vision loss or loss of the eye itself. Since endophthalmitis has a very poor prognosis, it is one of the most worrisome complications of cataract surgery. Cataract surgery is the most frequently performed operation in the world, and so eye surgeons must take strict prophylactic measures to prevent the development of endophthalmitis. The use of modern surgical techniques, tools, and materials, and compliance with asepsis and antisepsis rules has reduced the incidence of endophthalmitis considerably. In studies performed in Europe and the USA, the incidence of endophthalmitis following cataract surgery was reported as ranging between $0.06 \%$ and $0.49 \% .{ }^{[1,2]}$ Over the years, various methods of prophylactic antibiotic administration have been used before, during, and after surgical intervention. ${ }^{[3]}$ Preoperative eye drops have been found to be inadequate to prevent contamination of the anterior chamber. ${ }^{[4]}$ Preoperative conjunctival irrigation with $5 \%$ povidone iodine has become one of the standard steps of cataract surgery. ${ }^{[3]}$ Although there is great variation in the type and frequency of an antibiotic regimen applied after surgery, broad spectrum antibiotics are generally preferred. ${ }^{[3]}$ Among the prophylactic methods applied during surgery, subconjunctival administration of antibiotics has been replaced by intracameral applications due to the widespread preference for topical anesthesia in recent years. ${ }^{[3]}$ Since the publication of the guidelines of the European Society of Cataract and Refractive Surgeons (ESCRS) in 2007, use of intracameral cefurox- 
ime has become widespread. ${ }^{[2]}$ However, cefuroxime is not effective against some very virulent bacteria, such as some strains of Enterococcus, methicillin-resistant Staphylococcus aureus (MRSA), and Pseudomonas aeruginosa, and it requires some time to become effective. Therefore, studies in recent years have focused on broad-spectrum antibiotics, such as fourth-generation quinolones moxifloxacin and gatifloxacin, the effectiveness of which is less time-dependent. ${ }^{[5,6]}$ Although intraocular application of these drugs is highly effective, questions remain about safety. Therefore, the objective of this study was to compare the use of intracameral gatifloxacin with cefuroxime for endophthalmitis prophylaxis in terms of effectiveness and safety during cataract surgery, and to evaluate the long-term outcomes.

\section{MATERIAL AND METHODS}

After receiving approval of the proposed study's compliance with medical ethics from the scientific research evaluation committee, a total of 41 eyes of 33 patients diagnosed with a cataract between March 2012 and March 2013 were retrospectively included. The patients were divided into 2 groups according to the type of the antibiotic (cefuroxime or gatifloxacin) injected into the anterior chamber. Group I consisted of 18 eyes of 15 patients who received cefuroxime and Group 2 comprised 23 eyes of 18 patients who received gatifloxacin.

Signed, informed consent forms were obtained from all patients in accord with Declaration of Helsinki. Patient history of previous surgeries and preoperative systemic or ocular disease was determined. Patients with past or present corneal disease, glaucoma, uveitis, vitreous opacity, retinopathy, optic nerve or visual pathway defect, history of eye surgery, or use of systemic steroids, immunodepressants, anticoagulants, or prostaglandin analogues were excluded from the study. Patients who developed intraoperative complications were not included in the study. The best corrected visual acuity (BCVA) of all patients was measured from a distance of 6 meters using a Snellen chart before and after the operation. The values obtained were converted to LogMAR (logarithm of the minimum angle of resolution), and statistically evaluated.

Goldmann applanation tonometry was used to measure intraocular pressure. The evaluation of endothelial cell density (CD) and coefficient of variation (CV) was performed with a specular microscope (Topcon SP-2000P; Topcon America Corp, Paramus, NJ, USA), and central macular thickness (CMT) was measured using macular optical coherence tomography (Device name/number?; OPKO Instrumentation/OTI OPKO Health, Inc., Miami, FL, USA). The examinations were repeated at postoperative month I, 3, 6, and I2. The preoperative and postoperative measurements were compared within groups and the 2 groups were compared in terms of all measurements.
For the gatifloxacin group, 0.3\% gatifloxacin (Zymar; Allergan, Dublin, Ireland) was drawn into a $0.3-0.4 \mathrm{~mL}$ insulin syringe. The prepared solution was not subjected to any dilution; it was an intracameral solution of $\mathrm{pH} 6.0$ and osmolality 260-330 mOsm $/ \mathrm{kg}$. At the end of the operation, the solution was injected through a side port into the anterior chamber. In the other group, I vial $(250 \mathrm{mg})$ of cefuroxime (Zinnat; GlaxoSmithKline, London, England) was diluted to I $\mathrm{mg} / 0.1 \mathrm{~mL}$ with balanced physiological saline to achieve a prepared intracameral solution of $\mathrm{pH}$ of 7.28 and osmolality of $366 \mathrm{mOsm} / \mathrm{kg}$. At the end of the operation, the solution was injected into the anterior chamber through a side port.

The eyes of all patients were dilated preoperatively with $1.0 \%$ tropamide and $10.0 \%$ phenylephrine. Under local anesthesia, the skin was cleansed with $10 \%$ povidone iodine, and the conjunctival sac was disinfected for 3 minutes with $5 \%$ povidone iodine. Using a $2.8-\mathrm{mm}$ clear corneal side port, the nucleus was removed with the Stellaris phacoemulsification device (Bausch \& Lomb, Rochester, NY, USA) using the "stop and chop" method. Cortical remnants were removed with bimanual irrigation/aspiration, and an intraocular lens (AcrivaUD UD 613; VSY Biotechnology, Amsterdam, Netherlands) was implanted. Using bimanual irrigation/aspiration, an infusion of $10 \mathrm{mg} / \mathrm{mL}$ low-density I.0\% sodium hyaluronate (OVD BiVisc; Cima Technology, Inc., Pittsburgh, PA, USA) was administered and a 23-G cannula was used to infuse the antibiotic solution into the anterior chamber.

The patients were divided into 2 groups based on the antibiotic administered to the anterior chamber: Group I received $\mathrm{Img} / 0$. I $\mathrm{mL}$ cefuroxime and Group 2 received 0.3 $\mathrm{mg} / 0.1 \mathrm{~mL}$ gatifloxacin.

During the postoperative period, all of the patients received topical I\% prednisolone acetate (Pred Forte; Allergan, Dublin, Ireland). In addition patients received topical 0.5\% moxifloxacin (Vigamox; Alcon Laboratories, Inc., Ft. Worth, TX, USA) in Group I, and $0.3 \%$ gatifloxacin (Zymar; Allergan, Dublin, Ireland) in Group 2. For the first week, both were used every 2 hours, and every 4 hours in the second week. The treatment was discontinued at the end of the second week.

\section{Statistical analysis}

SPSS Statistics for Windows, Version 17.0 (SPSS Inc., Chicago, IL, USA) and Excel for Mac 20II (Microsoft Corp., Redmond, WA, USA) were used to analyze the data. Descriptive statistics (mean $\pm S D$ ) were used to describe the data, as well as a one sample t-test and independent t-test for comparisons of quantitative data and mean values between groups. The results were evaluated within a $95 \%$ confidence interval. The level of significance was established as $\mathrm{p}<0.05$. 


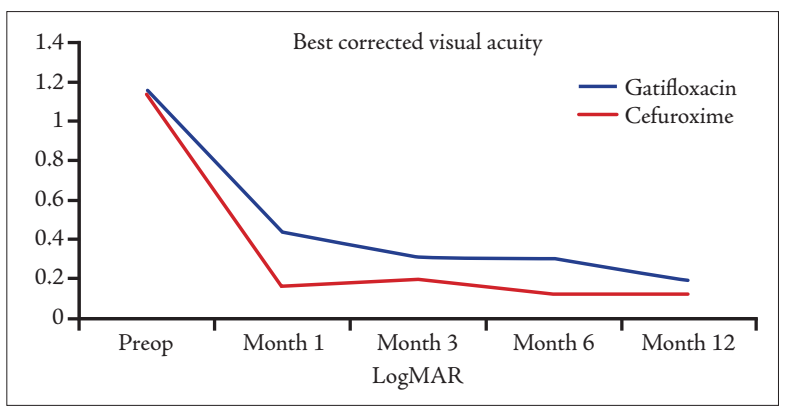

Figure 1. Percent change in visual acuity in both groups.

\section{RESULTS}

A total of $4 \mathrm{I}$ eyes of 33 patients who received an injection of cefuroxime $(1 \mathrm{mg} / 0.1 \mathrm{~mL})$ or moxifloxacin $(0.3 \mathrm{mg} / 0.1$ $\mathrm{mL}$ ) into the anterior chamber were evaluated. The median age of the patients was 7I.12 years (range: $30-90$ years); 19 were male $(57.6 \%)$ and 14 were female $(42.4 \%)$. In the cefuroxime group, 18 eyes of 15 patients were included, and 23 eyes of 18 patients made up the gatifloxacin group. A statistically significant difference was not observed with regard to gender, mean age, preoperative $B C V A, C D, C V$, or CMT $(p>0.05)$.

\section{Visual acuity}

A statistically significant increase in BCVA was observed in both groups at postoperative month I, 6, and 12 $(p=0.000)$. The preoperative BCVA value of the 2 groups was statistically comparable $(p=0.855)$.

The mean I-month BCVA value in the gatifloxacin group was significantly higher than that of the cefuroxime group $(p=0.014)$. No other statistically significant difference between the 2 groups was observed in the mean BCVA measurements $(p>0.05)$ (Table I, Fig. I).

\section{Endothelial cell density}

No significant difference was seen between groups in the mean preoperative or postoperative month I CD level $(p=0.068)$. In both groups, the postoperative month 6 and month 12 mean CD value was significantly lower compared with the corresponding mean preoperative value (gatifloxacin: $p=0.002$; cefuroxime: $p=0.020$ ) (Table 2).

No statistically significant difference was found between the gatifloxacin and cefuroxime groups in $C D$ measured preoperatively or at postoperative month I, 3, 6, or 12 $(p>0.05)$.

Table I. Intergroup comparison of the best corrected visual acuity values

\begin{tabular}{lllll}
\hline Best corrected visual acuity & Intracameral drug & Mean & Standard deviation & p \\
\hline Preoperative & Gatifloxacin & 1.2565 & 0.44192 & 0.940 \\
& Cefuroxime & 1.2667 & 0.40873 & 0.44096 \\
Postoperative month I & Gatifloxacin & 0.4295 & 0.15736 & $0.014^{*}$ \\
& Cefuroxime & 0.1412 & 0.51026 & 0.154 \\
Postoperative month 3 & Gatifloxacin & 0.3476 & 0.19208 & 0.245 \\
Postoperative month 6 & Cefuroxime & 0.1706 & 0.24149 & 0.16444 \\
Postoperative month 12 & Gatifloxacin & 0.1886 & 0.1118 & 0.24149 \\
& Cefuroxime & 0.1876 & 0.16444 &
\end{tabular}

Table 2. Comparison of endothelial cell density as assessed with a specular microscope

\begin{tabular}{lllcc}
\hline Endothelial cell density & Gatifloxacin & Cefuroxime & p value gatifloxacin & p value cefuroxime \\
\hline Preoperative & 1716.5652 & 1878.6667 & $\mathrm{p}=0.273$ & $\mathrm{p}=0.068$ \\
Postoperative month I & 1629.9048 & 1570.8824 & $\mathrm{p}=0.002^{*}$ & $\mathrm{p}=0.020^{*}$ \\
Preoperative & 1716.5652 & 1878.6667 & & $\mathrm{p}=0.020^{*}$ \\
Postoperative month 6 & 1449.9091 & 1474.9412 & $\mathrm{p}=0.002^{*}$ & \\
Preoperative & 1716.5652 & 1878.6667 & & \\
Postoperative month 12 & 1446.3636 & 1474.2941 & &
\end{tabular}




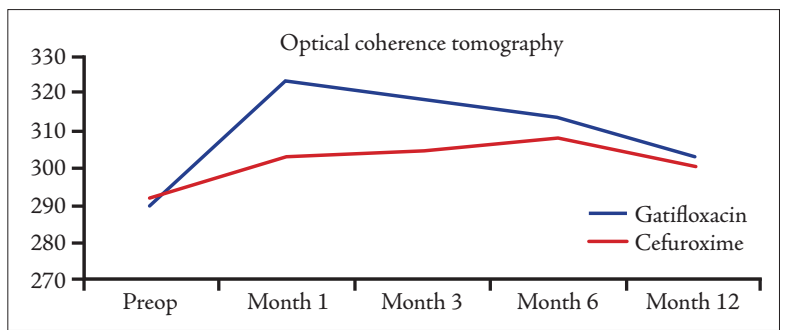

Figure 2. Changes in optical coherence tomography measurements of mean central macular thickness.

\section{Endothelial cell variation coefficient}

In the gatifloxacin group, the mean preoperative CV was significantly lower than that determined for postoperative month I, 6, and $12(p=0.00)$; however, in the cefuroxime group, the mean $\mathrm{CV}$ at postoperative month I was significantly lower than the preoperative $C V(p=0.01)$. No significant difference was seen between the mean $C V$ preoperative value and postoperative month 6 or 12 ( $p>0.05)$.

The mean CV postoperative month I was higher in the cefuroxime group when compared with the gatifloxacin group, while the mean preoperative $\mathrm{CV}$ and at postoperative month 3, 6, and I 2 was higher in the gatifloxacin group. However, the mean preoperative, and postoperative month I, 6, and $12 \mathrm{CV}$ value did not differ significantly between the gatifloxacin and cefuroxime groups $(p>0.05)$ (Table 3$)$.

Table 3. Intergroup comparison of mean endothelial cell coefficient of variation as evaluated with a specular microscope

\begin{tabular}{lccc}
\hline CV & Gatifloxacin & Cefuroxime & $\mathbf{p}^{*}$ \\
\hline Preoperative & 21.9500 & 22.8182 & $=0.720$ \\
Postoperative month I & 28.5263 & 31.3125 & $=0.292$ \\
Postoperative month 3 & 28.5000 & 26.4000 & $=0.484$ \\
Postoperative month 6 & 36.6667 & 26.8125 & $=0.230$ \\
Postoperative month 12 & 35.7619 & 26.6250 & $=0.269$ \\
\hline
\end{tabular}

$*$ One-sample test $(p<0.05)$. CV: Endothelial cell coefficient of variation.

\section{Central macular thickness}

In the gatifloxacin group, the mean preoperative CMT was significantly lower when compared with the mean CMT at postoperative month I, 6, and $12(p<0.05)$. However, in the cefuroxime group, CMT measurements performed during the follow-up period did not reveal any significant difference between the mean preoperative and postoperative month I, 6, or 12 values ( $>>0.05)$ (Table 4).

Although intragroup changes in CMT measurements differed, no significant intergroup difference was observed in the mean preoperative and postoperative month I, 6, and 12 CMT values ( $p>0.05)$ (Fig. 2).

Endophthalmitis was not seen in any of the patients in the cefuroxime group $(n=18)$ or the gatifloxacin group $(n=23)$ in postoperative month $1,3,6$, or 12 .

\section{DISCUSSION}

Postoperative endophthalmitis is a rare but very serious potential complication following cataract surgery. Among the risk factors for the development of endophthalmitis are the patient's age, contamination of the anterior chamber, the surgical technique used, and the presence of other complications. ${ }^{[2,7,8]}$ It typically occurs within the first few hours, and the positive rate reported in cultures of anterior chamber irrigation solution have ranged between $2 \%$ and $40 \% .^{[7,8]}$ Therefore, a need exists for effective prophylactic measures against endophthalmitis. Pre- and postoperative use of a topical antibiotic, such as povidone iodine; subconjunctival antibiotherapy; the addition of an antibiotic to the irrigation solution; oral systemic antibiotherapy; and the intracameral application of bolus doses of antibiotics have been used, as well as the intracameral injection of antibiotics, which has become the predominant method. ${ }^{[9]}$ However a final determination of the safe dose of antibiotic for intraocular tissues is not yet certain. Despite multiple large-scale studies of prophylactic treatment with antibiotics, including vancomycin, cefuroxime, cefazolin, and moxifloxacin, a consensus has not yet been reached among the ophthalmology community. ${ }^{[2,5,10,1}$ I]

Table 4. Comparison of intragroup mean central macular thickness values based on OCT measurements

\begin{tabular}{lcccc}
\hline Central macular thickness $\boldsymbol{\mu}$ & Gatifloxacin & Cefuroxime & p value gatifloxacin* & p value cefuroxime $^{*}$ \\
\hline Preoperative & 289.9524 & 291.8571 & $=0.000$ & $=0.314$ \\
Postoperative month I & 323.2857 & 303.1429 & & $=0.000$ \\
Preoperative & 289.9524 & 291.8571 & & $=0.158$ \\
Postoperative month 6 & 313.3182 & 308.0000 & $=0.012$ & $=0.423$ \\
Preoperative & 289.9524 & 291.8571 & & \\
Postoperative month I2 & 303.3182 & 300.7647 & & \\
\hline
\end{tabular}

*One-sample test $(p<0.05)$. OCT: Optical coherence tomography. 
Microbial flora of the eyelid or the conjunctiva are a frequent source of postoperative infection; however the contaminant may also be airborne, or be introduced in the intraocular solution, lenses, surgical devices, or by operating room personnel. ${ }^{[12,13]}$ Whatever the source of the contamination, a prophylactic antibiotic should penetrate the anterior chamber to decrease the bacterial burden. Therefore, the ideal antibiotic should be effective against a broad spectrum of bacteria types, have low toxicity, and easily penetrate to the anterior chamber. ${ }^{[6,10]}$ The technique of administering antibiotics to the anterior chamber has become a highly preferred method due to the high intraocular bioavailability and effective intraocular concentration in the first postoperative hours. ${ }^{[14]}$

Vancomycin was the first antibiotic injected into the anterior chamber postoperatively; however, intracameral use was abandoned within a short time as a result of encountering problems of resistance and retinal toxicity. ${ }^{[10]}$ Since then, based on the results of a multicenter study released by the ESCRS, intracameral use of cefuroxime has been recommended and used. ${ }^{[2,15]}$

Cefuroxime is a second-generation cephalosporin that is effective against Gram-positive and Gram-negative microorganisms. However, intracameral use is limited since its effect is time-dependent; it is ineffective against MRSA, some strains of Enterococcus, and Pseudomonas aeruginosa; and it has allergenic characteristics. Montan et al. ${ }^{[14]}$ concluded in their study that intracameral use of $\mathrm{I} \mathrm{mg/0.I}$ $\mathrm{mL}$ cefuroxime was safe and not toxic to endothelial or retinal cells. Yet, they also reported that cefuroxime-resistant bacterial isolates were grown in cultures of 12 out of I 3 samples. Friling et al. ${ }^{[16]}$ reported in a 2013 study of the Swedish National Cataract Registry that cefuroxime had not been found to be effective in recent years, and that the proportion of enterococcal infections had increased to $31 \%$. However, they noted that this was likely to be related to a proportional decrease in common etiological agents of endophthalmitis. Though there has been a significant decrease in the incidence rate of endophthalmitis with the intracameral use of cefuroxime, we are still faced with the need for a broad-spectrum antibiotic that can be safely injected into the anterior chamber.

Many surgeons have recently preferred to use fourth-generation quinolones, due to the fact that they are effective against a broad antibacterial spectrum, the mechanisms of action are independent from the time of administration, and they are manufactured in ready-to-use concentrations. [17,18] The effectiveness, reliability, and safety of $0.5 \mathrm{mg} / 0.1$ $\mathrm{mL}$ moxifloxacin has been reported in many studies performed in our country and abroad. ${ }^{[17,18]}$ In the present study, we compared effectiveness and safety of cefuroxime, which is recognized as safe for intraocular use, with gatifloxacin, another fourth-generation quinolone.
Although gatifloxacin has a Gram-positive activity similar to that of moxifloxacin and a slightly more pronounced Gram-negative activity, the current form of the drug on the market (0.3\% Zymar; Allergan, Dublin, Ireland) contains benzalkonium chloride, which is not preferred intracamarally. ${ }^{[19]}$ Choi et al. ${ }^{[20]}$ conducted a study in 2009 and examined 24 eyes of New Zealand White rabbits randomized into 3 groups. Two groups were given $0.3 \mathrm{mg} / 0.1 \mathrm{~mL}$ gatifloxacin or $0.5 \mathrm{mg} / 0 . \mathrm{I} \mathrm{mL}$ levofloxacin, and the control group was given $0.1 \mathrm{~mL}$ sterile BSS irrigating solution (Alcon Laboratories, Inc., Hunenberg, Switzerland). Slit lamp biomicroscopic examination of thin sections was performed 3 and 7 days after administration to score clinical toxicity, and pachymetric measurements were made to detect endothelial cell toxicity. The percentage of nonviable endothelial cells was analyzed using a screening electron microscope and a transmission electron microscope. The results revealed higher clinical and cellular toxicity scores in all groups, including the control group. However, no statistically significant intergroup difference was seen. The gatifloxacin group and the control group were comparable in terms of the size of the increase in basal pachymetry values and electron microscopic examination findings, while a loss of cell microvilli and irregular cell contours were detected in the levofloxacin group, which was interpreted as the presence of greater cellular toxicity. It was concluded that the use of intracameral gatifloxacin was not toxic to endothelial cells. Similarly, in our study, specular microscopy examination of the patients who received a gatifloxacin injection into the anterior chamber did not reveal a statistically significant difference between pre- and postoperative findings related to $C D$ or $C V(p>0.05)$.

Snyder et al. ${ }^{[2]}$ published a study investigating the effect of an intracameral injection of gatifloxacin on the retinal cells of rabbits in which they took photos of the fundus and the optic nerve I day and 28 days after the administration of the drug. In addition, electroretinogram (ERG) and visually evoked potential measurements were performed, and the retina was histologically analyzed. No toxic effect on retinal cells was observed as a result of intracameral injection of gatifloxacin. Kazi et al. ${ }^{[22]}$ also reported that intravitreal injections of gatifloxacin up to $400 \mu \mathrm{g}$ were not found to be toxic to the retina of rabbits based on ERG measurements performed on the $14^{\text {th }}$ day. In our study, assessments of CMT performed after an intracameral gatifloxacin injection did not reveal a statistically significant difference relative to preoperative values; we concluded that the application was not retinotoxic.

We have arrived at a conclusion that an injection of cefuroxime or gatifloxacin to the anterior chamber has similar effects on the retinal and endothelial tissues, and both drugs can be used safely. However, in the present study, our inability to examine corneal pachymetric changes or to evaluate hexagonality, which is an indicator of pleomor- 
phism, are limitations. Additional, larger case series should be conducted.

\section{Ethics Committee Approval}

Approval has been obtained from the Ethics Committee.

Informed Consent

Approval was obtained from the patients.

Peer-review

Internally peer-reviewed.

Authorship Contributions

Concept: A.P., I.K.K.; Design: Y.Ö., M.A.; Data collection \&/or processing: A.P., I.K.K.; Analysis and/or interpretation: A.P., M.A.; Literature search: I.K.K., A.P.; Writing: A.P.; Critical review: Y.Ö.

Conflict of Interest

None declared.

\section{REFERENCES}

1. Taban M, Behrens A, Newcomb RL, Nobe MY, Saedi G, Sweet PM, et al. Acute endophthalmitis following cataract surgery: a systematic review of the literature. Arch Ophthalmol 2005;123:613-20. [CrossRef]

2. Endophthalmitis Study Group, European Society of Cataract $\&$ Refractive Surgeons. Prophylaxis of postoperative endophthalmitis following cataract surgery: results of the ESCRS multicenter study and identification of risk factors. J Cataract Refract Surg 2007;33:978-88.

3. Barry P, Covdoves L, Gardner S. Katarakt Cerrahisi Sonrası Endoftalminin Önlenmesi ve Tedavisi için ESCRS Rehberleri. 1. baskı. Dublin: Temple Road; 2014. p. 2-31.

4. Chitkara DK, Manners T, Chapman F, Stoddart MG, Hill D, Jenkins D. Lack of effect of preoperative norfloxacin on bacterial contamination of anterior chamber aspirates after cataract surgery. $\mathrm{Br} \mathrm{J} O \mathrm{Oph}$ thalmol 1994;78:772-4. [CrossRef]

5. Lane SS, Osher RH, Masket S, Belani S. Evaluation of the safety of prophylactic intracameral moxifloxacin in cataract surgery. J Cataract Refract Surg 2008;34:1451-9. [CrossRef]

6. O'Brien TP, Arshinoff SA, Mah FS. Perspectives on antibiotics for postoperative endophthalmitis prophylaxis: potential role of moxifloxacin. J Cataract Refract Surg 2007;33:1790-800. [CrossRef]

7. Baillif S, Roure-Sobas C, Le-Duff F, Kodjikian L. Aqueous humor contamination during phacoemulsification in a university teaching hospital. J Fr Ophtalmol 2012;35:153-6. [CrossRef]

8. Dickey JB, Thompson KD, Jay WM. Anterior chamber aspirate cultures after uncomplicated cataract surgery. Am J Ophthalmol 1991;112:278-82. [CrossRef]

9. Liesegang TJ. Intracameral antibiotics: questions for the United States based on prospective studies.J Cataract Refract Surg 2008;34:505-9.

10. Tipperman R. Pharmacologic considerations for cataract surgery. Curr Opin Ophthalmol 2004;15:51-5. [CrossRef]

11. Tan CS, Wong HK, Yang FP. Epidemiology of postoperative endophthalmitis in an Asian population: 11-year incidence and effect of intracameral antibiotic agents. J Cataract Refract Surg 2012;38:425-30.

12. Peyman G, Lee P, Seal DV. Endophthalmitis diagnosis and management. 1st ed. London: Taylor \& Francis; 2004. p. 1-270. [CrossRef]

13. Kanski JJ. Acute Bacterial Endophthalmitis. In: Clinical Ophthalmology. 6th ed. London; Butterworth-Heinemann; 2007. p. 354-9.

14. Montan PG, Wejde G, Setterquist H, Rylander M, Zetterström C. Prophylactic intracameral cefuroxime. Evaluation of safety and kinetics in cataract surgery. J Cataract Refract Surg 2002;28:982-7. [CrossRef]

15. Barry P, Seal DV, Gettinby G, Lees F, Peterson M, Revie CW; ESCRS Endophthalmitis Study Group. ESCRS study of prophylaxis of postoperative endophthalmitis after cataract surgery: Preliminary report of principal results from a European multicenter study. J Cataract Refract Surg 2006;32:407-10. [CrossRef]

16. Friling E, Lundström M, Stenevi U, Montan P. Six-year incidence of endophthalmitis after cataract surgery: Swedish national study. J Cataract Refract Surg 2013;39:15-21. [CrossRef]

17. Ekinci Koktekir B, Aslan BS. Safety of prophylactic intracameral moxifloxacin use in cataract surgery. J Ocul Pharmacol Ther 2012;28:278-82. [CrossRef]

18. Matsuura K, Suto C, Inoue Y, Sasaki S, Odawara S, Gotou T. Safety of intracameral injection of moxifloxacin using total replacement technique (bag and chamber flushing). J Ocul Pharmacol Ther 2014;30:771-6.

19. Olson R. Zymar as an ocular therapeutic agent. Int Ophthalmol Clin 2006;46:73-84. [CrossRef]

20. Choi JA, Chung SK. Safety of intracameral injection of gatifloxacin, levofloxacin on corneal endothelial structure and viability. J Ocul Pharmacol Ther 2009;25:425-31. [CrossRef]

21. Snyder RW, Chang M, Hare W, et al. Intraocular safety of gatifloxacin in a rabbit model. Paper presented at: The Ocular Microbiology Immunology Group Meeting (OMIG); November 15, 2003; Anaheim, CA.

22. Kazi AA, Jermak CM, Peyman GA, Aydin E, Riazi-Esfahani M. Intravitreal toxicity of levofloxacin and gatifloxacin. Ophthalmic Surg Lasers Imaging 2006;37:224-9.

\section{Katarakt Cerrahisi Sonrası Profilaktik Intrakamaral Gatifloksasin Uygulamasının Etkinlik ve Güvenliliği: Bir Yıllık Takip Sonuçları}

Amaç: Katarakt cerrahisi sonrası endoftalmi profilaksisinde intrakamaral gatifloksasin ve sefuroksim kullanımının etkinlik ve güvenlilik açısından karşılaştırılması.

Gereç ve Yöntem: Geriye dönük karşılaştırmalı olgu çalışması olarak 33 hastanın 4 I gözü iki gruba ayrıldı. Birinci grupta 18 göze fakoemülsifikasyon sonrası intrakamaral I mg/0.I mL sefuroksim, ikinci gruptaki 23 göze intrakamaral $300 \mu \mathrm{g} / 0.1 \mathrm{~mL}$ gatifloksasin verildi. Ameliyat öncesi ve sonrası birinci, üçüncü ve altıncı ay ve birinci yıldaki en iyi düzeltilmiş görme keskinliği (EDGK), endotelyal hücresel yoğunluk değeri (CD), endotelyal hücresel varyasyon katsayısı (CV) ve santral maküler kalınlık (SMK) ölçümleri değerlendirildi.

Bulgular: Bir yıllık takip sonunda hiçbir hastada akut/kronik endoftalmi, kistoid maküler ödem, büllöz keratopati gibi ciddi komplikasyonlar görülmedi. Her iki grupta da ameliyat sonrası birinci ayda istatistiksel olarak anlamlı derecede EDGK'de artış yanında CD'de azalma ve SMK'da istatistiksel olarak anlamlı olmayan artış eğilimi görüldü. Ancak takiplerde elde edilen EDGK, CD, CV, SMK değerleri açısından iki grup istatistiksel olarak benzer bulundu $(p>0.05)$.

Sonuç: Bir yıllık takiplerin tamamında iki grup EDGK, CD, CV, SMK ölçümleri açısından istatistiksel olarak benzer bulunduğundan ( $p>0.05$ ), ameliyat sonrası CD değerindeki azalma cerrahi yöntemin kendisi ile ilişkilendirildi. Her iki grupta ameliyat sonrası birinci ayda görülen SMK'daki artış eğilimi ise istatistiksel ve klinik açıdan anlamsız olduğundan $300 \mu \mathrm{g} / 0.1 \mathrm{~mL}$ gatifloksasinin intrakamaral uygulanmasının, I $\mathrm{mg} / 0$. I mL sefuroksim ile benzer olarak endoftalmi profilaksisi amacıyla kullanımının etkin ve güvenli olabileceği sonucuna ulaşılmıştır.

Anahtar Sözcükler: Endoftalmi; gatifloksasin; intrakamaral; katarakt; profilaksi, sefuroksim. 